\title{
Impact of vegetation on the mobility and bioavailability of trace elements in a dredged sediment deposit: a greenhouse study
}

\author{
Fabienne Marseille*, Christophe Tiffreau, Agnès Laboudigue, \\ Paul LECOMTE
}

Centre National de Recherche sur les Sites et Sols Pollués, 930 bd Lahure, BP 537, 59505 Douai, France

(Received 16 September 1999; revised 13 January 2000; accepted 27 January 2000)

\begin{abstract}
In France, high quantities of heavy metal contaminated sediments are dredged each year and deposited on soils without any protection. Despite their high pollutant content, a vegetal cover generally appears spontaneously on these deposits. However, the growth of plants on the sediments can have an impact on the heavy metal behaviour. In order to evaluate this impact, a greenhouse experimentation was designed to measure the heavy metal (zinc, cadmium, lead, copper) mobilisation during the growth of different vegetal species, and their absorption by vegetation. The results indicate that high concentrations of heavy metals are absorbed by the plants. Moreover, the establishment of a vegetal cover (maize, rape and rye grass) on dredged sediments is able to quantitatively modify the physico-chemical parameters of the sediments, and to increase the mobility of the heavy metals inside.
\end{abstract}

heavy metal / revegetation / mobility / bioavailability / dredged sediment

Résumé - Impact de l'installation d'un couvert végétal sur la mobilité de métaux présents dans des sédiments de curage : Etude en serre. En France, des quantités importantes de sédiments contaminés par des polluants métalliques sont curées chaque année, et déposées à même le sol sans précautions particulières. En dépit de leurs concentrations élevées en métaux, ces dépôts se revégétalisent spontanément, ce qui peut entraîner, à travers une évolution différente des caractéristiques physicochimiques du sédiment, des changements de mobilité et de biodisponibilité des métaux. Afin d'évaluer cet impact, une étude a été conduite en serre pour mesurer la mobilisation des métaux lors de la culture de différentes espèces végétales; maïs, ray grass et colza. L'absorption des métaux par les différentes espèces a également été suivie. Les résultats présentés dans cette étude montrent que des quantités importantes de métaux sont absorbées par la végétation. Ils indiquent également que l'installation d'un couvert végétal influe sur les caractéristiques physico-chimiques de la matrice solide, induisant ainsi une augmentation de la mobilité des métaux.

métal / revégétation / mobilité / biodisponibilité / sédiment de curage

Communicated by Isabelle Lamy

* Correspondence and reprints

marseille@cnrssp.org 


\section{Introduction}

In the North of France, $450000 \mathrm{~m}^{3}$ of sediments are dredged each year during maintenance operations of rivers and channels. A large part of this dredged material (more than 1/3) can be considered as contaminated by significant amounts of chemical pollutants such as heavy metals [5]. Due to the large amount of sludge generated and the cost of incineration and dumping, dredged materials are generally deposited along streams or in deposit sites without any specific protection. Depending on their mobility and biodisponibility, heavy metals can thus be transferred to the soil, the groundwater and the vegetation and in this way enter the food chain. Therefore, it is urgent to resolve the problems issued from these deposits, specially about their impact on the surrounding environment, including the flora, the fauna and consequently man.

The observation of ancient deposit sites, and the monitoring (for two years) of a test deposit set up by the National Research Centre for Polluted Sites and Soils [27] showed that, despite the high heavy metal content, a vegetal cover naturally occurs on the sediment deposits. Numerous studies reveal that revegetation of heavy-metal contaminated sites may reduce transport of heavy metals by the reduced runoff, the wind and water erosion, and by limiting hydric transfers throughout the soil profile. As a matter of fact, the establishment of a vegetation (i.e. phytostabilisation) is one of the methods frequently used for the reclamation of sites heavily polluted by mining or smelting activities [7, 22, 23, 28].

However, several mechanisms occur for modifying the chemical and the physical extent of rhizosphere, in order to enhance the micronutrient bioavailability [20]. As a consequence, modifications can occur directly as a result of the root activity, or indirectly through the effects of the microbial activity stimulated in rhizosphere by root exudates. For instance, organic acids produced in the rhizosphere, can increase the mobility and thus the bioavailability of heavy metals as a result of acidification and complexation [3, 4]. Roots can also induce changes in the ionic concentration and the redox conditions in the rhizosphere what can modify the heavy-metal mobility [10, 20]. Especially, in the case of dredged sediments, changes induced by the establishment of a vegetal cover can be much more dramatic than for a soil matrix. In fact, dredged sediments are initially typical anoxic materials. Once in an aerial deposit, they will be progressively oxygenated, thus inducing major changes of the oxydo reduction potential, the $\mathrm{pH}$, the conductivity and the speciation of major and trace elements $[8,24,25]$. As a consequence, vegetation may enhance or slow down the sediment evolution, leading to differences in the behaviour of heavy metals. For instance, root development can result in sediment destructuration and de-hydratation and induce a better aeration of the sediment, thus leading to an increase of Eh in the rhizosphere area.

In order to evaluate the effects of plant development on the sediment matrix evolution, a greenhouse experiment was carried out. Distinct plant species (maize, rye grass and rape) have been chosen according to their specific influence on the substrate. So, rape is able to excrete protons in its rhizosphere in order to mobilise nutrients whereas rye grass and maize are not [10]. The heavy metal concentrations were determined in the pot leachates and in the roots and the shoots of the three species as well as the evolution of the physico-chemical parameters in the leachates $(\mathrm{pH}, \mathrm{Eh}$, dissolved organic carbon, etc.).

\section{Materials and methods}

\subsection{Sediment and vegetation characteristics}

The sediments were collected in the Scarpe river in the North of France downstream from a zinc plating plant. The sediments were kept for one month in open buckets before using for culture (in order to aerate the matrix and reduce its water content to an acceptable level). They were prevently homogenised and mixed with sand to enhance their permeability (preliminary tests showed that this 
Table I. Heavy metal concentrations and main characteristics of the dredged material after one month aeration.

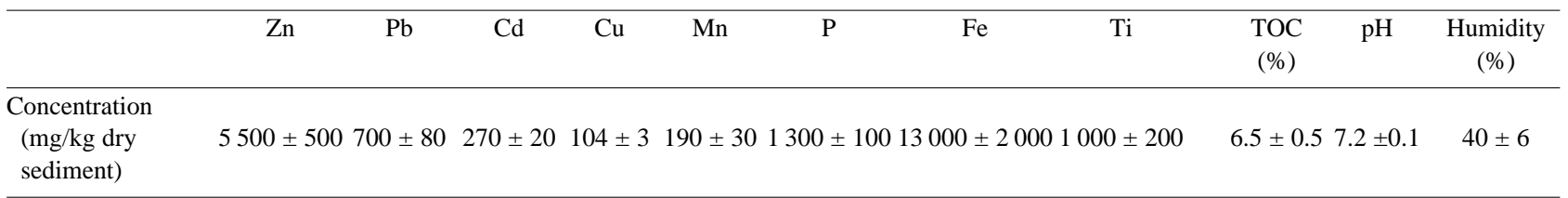

mixing was necessary in order to ensure sufficient water infiltration and draining). Table I summarises the heavy metal concentrations and the main characteristics of the sediment. They are typical anaerobic materials of a river bottom with low Eh, the occurrence of sulphide minerals and a high organic matter content. Complementary information is given by Isaure et al. [12] and Tiffreau et al. [27].

The species used in the study are maize (Zea mais, DK 256 variety), rape (Brassica napus, Tanto variety) and rye grass (Lolium perenne, Nüman variety).

\subsection{Experimental design (Fig. 1)}

Two kg of wet dredged sediments (40\% moisture) were mixed with $1 \mathrm{~kg}$ of sand and used to fill plastic pots in a greenhouse. Seeds were directly hand sown in the sediments. The experiment was carried out with eight pots of each species and six reference pots without vegetation. After one month, the less developed seedlings were pulled out, in

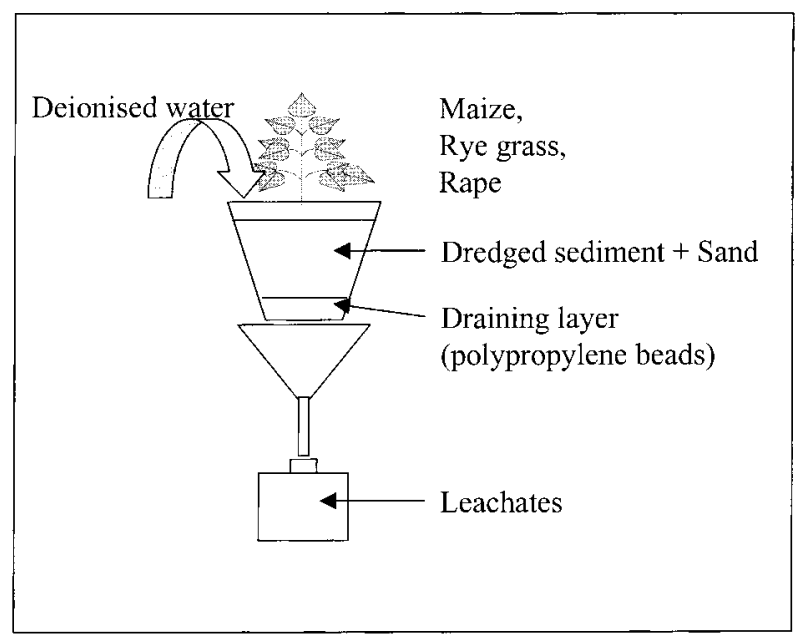

Figure 1. Experimental scheme used in the experimentation. order to keep the same number of plants by pot: two for maize and four for rape. For rye grass, $2 \mathrm{~g}$ of seeds were sown in each pot without modification during growing. Along the whole growth period (from the beginning of June to the end of October), plants were followed, representing a complete cycle for maize and rape. The growing occurs without artificial lighting. Pots were irrigated daily with deionised water and amended with nitrogen $\left(\mathrm{NaNO}_{3}, 0.06 \mathrm{mg}\right.$, three times a week).

\subsection{Analytical procedure}

\subsubsection{Leachates}

Every week, leachates were collected into plastic bottles, installed under the pots. The aliquots reserved for the metal analysis were acidified $\left(\mathrm{HNO}_{3}\right.$, p.a.), stored at $4{ }^{\circ} \mathrm{C}$ until their analysis and filtered before analysis. The determination of $\mathrm{Zn}$, $\mathrm{Mn}, \mathrm{Fe}$ and $\mathrm{P}$ was carried out by Inducted Coupled Plasma-Optical Emission Spectroscopy (ICP-AES Jobin-Yvon, JY 138 ultrace), and the determination of $\mathrm{Pb}, \mathrm{Cd}$ and $\mathrm{Cu}$ by graphic furnace Atomic Absorption Spectrophotometry (Varian SpectrAA). The aliquots used for the dissolved organic carbon (DOC) measurement were poisoned with sodium azide and stored at $4{ }^{\circ} \mathrm{C}$ to prevent the development of micro-organisms. The non purgeable organic carbon was determined with a TOC 5000A Shimatzu.

\subsubsection{Plants}

Half of the pots were harvested and dismantled after three months of growth, the others growing two months more. Collected roots and shoots were thoroughly washed with deionised water, dried at $60{ }^{\circ} \mathrm{C}$ for $48 \mathrm{~h}$ and ground with a waring blendor. Plant analysis for major and trace elements were 
Table II. $\mathrm{Zn}, \mathrm{Pb}, \mathrm{Cd}, \mathrm{Cu}, \mathrm{Mn}, \mathrm{Fe}$ and $\mathrm{P}$ concentrations (mean and standard deviations $(\mathrm{n}=4)$ in $\mathrm{mg} / \mathrm{kg}$ dry weight) in roots and shoots of maize, rape and et rye grass after three months of growth [6].

\begin{tabular}{lccccrcc}
\hline $\begin{array}{c}\text { Concentration } \\
(\mathrm{mg} / \mathrm{kg})\end{array}$ & $\mathrm{Zn}$ & $\mathrm{Fe}$ & $\mathrm{Mn}$ & $\mathrm{Pb}$ & $\mathrm{Cd}$ & $\mathrm{Cu}$ & $\mathrm{P}$ \\
\hline Maize (shoots) & $800 \pm 130$ & $80 \pm 21$ & $150 \pm 27$ & $3 \pm 1$ & $3 \pm 1$ & $15 \pm 8$ & $2700 \pm 369$ \\
Rape (shoots) & $1900 \pm 139$ & $70 \pm 16$ & $200 \pm 24$ & $2 \pm 1$ & $10 \pm 2$ & $13 \pm 1$ & $4100 \pm 421$ \\
Rye grass (shoots) & $1100 \pm 200$ & $500 \pm 256$ & $400 \pm 88$ & $17 \pm 6$ & $12 \pm 5$ & $60 \pm 29$ & $5400 \pm 323$ \\
\hline Maize (roots) & $1700 \pm 174$ & $700 \pm 276$ & $190 \pm 56$ & $30 \pm 12$ & $34 \pm 6$ & $40 \pm 10$ & $1000 \pm 474$ \\
Rape (roots) & $3600 \pm 373$ & $5000 \pm 607$ & $200 \pm 49$ & $200 \pm 34$ & $120 \pm 26$ & $80 \pm 14$ & $21000 \pm 345$ \\
Rye grass (roots) & $3000 \pm 442$ & $4000 \pm 1623$ & $300 \pm 114$ & $140 \pm 57$ & $80 \pm 36$ & $80 \pm 10$ & $22000 \pm 5700$
\end{tabular}

carried out after digestion of $1 \mathrm{~g}$ of ground sample in a mixture of $\mathrm{HNO}_{3}(2.5 \mathrm{~mL})$ and $\mathrm{HCl}(7.5 \mathrm{~mL})$ for 12 hours at room temperature and 2 hours under reflux heating.

This digestion procedure has been chosen after a preliminary comparison of four digestion procedures: (1) 4 hours calcination at $450{ }^{\circ} \mathrm{C}$ and the use of hydrofluoric and perchloric acids for the digestion, (2) no calcination and digestion of the sample with hydrogen peroxide and nitric acid, (3) no calcination and digestion with hydrochloric and nitric acids at room temperature and (4) digestion with the same acids under reflux. These tests showed that the first and the fourth procedures were the more efficient methods in terms of extraction rates and repeatability [6]. However, the fourth procedure has been preferred to the first one because this latter includes a calcination step and the use of hydrofluoric acid. The analyses were carried out in triplicate. The contents of $\mathrm{Zn}, \mathrm{Pb}, \mathrm{Cu}, \mathrm{Cd}, \mathrm{Fe}$ and $\mathrm{Mn}$ were determined by ICP-AES.

\subsection{Statistical study}

For leachates, the graphical data is concerned with the average of eight replicates for the June to September period, and four for the September to November period.

These results were statistically tested in order to evidence significant differences between the three plant species and reference pots. The KruskalWallis test (median comparison) has been used because of the non-normality of the variables.

\section{Results and discussion}

\subsection{Heavy-metal content in vegetation}

Trace and major element data in the roots and the shoots of maize, rape and rye grass are summarised in Table II. These values are the average values obtained in plants collected half-way through time of growing.

Zinc concentrations in shoots range between $800 \mathrm{mg} / \mathrm{kg}$ (maize) and $1900 \mathrm{mg} / \mathrm{kg}$ (rape) on the dry weight basis. These concentrations are considerably higher than concentrations generally presented in the literature. Indeed "normal" concentrations are mentioned to be smaller than $150 \mathrm{mg} / \mathrm{kg}$, and excessive or toxic concentrations range between 100 and $400 \mathrm{mg} / \mathrm{kg}[2,14]$. Other heavy-metal concentrations in shoots $(\mathrm{Cd}, \mathrm{Cu}, \mathrm{Pb}, \mathrm{Fe})$ do not present such important differences compared to the literature data. The high concentrations of zinc in vegetation can be related to its large total concentration in the sediment $(5500 \mathrm{mg} / \mathrm{kg})$, cumulated with its wide availability. As a matter of fact, zinc is usually considered to have a higher mobility in a soil than copper or lead [22].

Moreover, the absorption of heavy metals by plants seems specific of the element [2]. For instance, the rate of copper, an essential plant micro nutrient, is directly regulated inside the plants, where its content tends to be constant and relatively independent of the nature of the substrate. Conversely lead, which is neither an essential nor 
beneficial element, is regulated outside the plants as it is usually precipitated very quickly in the rhizosphere, hence minimising its uptake. Finally, zinc, which is also an essential element, is present in large quantities in plants. Its concentration is higher than copper, around $100 \mathrm{mg} / \mathrm{kg}$ [14] and it can be largely accumulated by the vegetation. The dispersion of zinc concentration in shoots is very high and concentrations of $1000 \mathrm{mg} / \mathrm{kg}$ are not considered uncommon.

In addition to these parameters, the absorption of metals is also dependent on the plant species. Rape absorbs and transfers more specifically zinc and cadmium to its shoots. This specificity could be linked to the ability of this species to acidify its rhizosphere and thus to increase the $\mathrm{Zn}$ availability. However, this availability increase is not the lonely hypothesis to explain the very high concentrations in rape, and could also be related to a higher density of zinc transporters in rape roots than in the other species studied. Numerous studies highlighted that changes induced in the rhizosphere of Thlaspi caerulescens are not able to explain the hyperaccumulation of zinc by this species [16, 21]. Particularly, the comparison of the rhizosphere characteristics of a zinc hyperaccumulator species (T. caerulescens) with zinc tolerant species (T. ochroleucum, T. arvense, wheat) grown on the same soils did not show any difference in $\mathrm{pH}$ and Zn availability [9, 17, 18].

Rye grass shoots present smaller zinc concentrations compared to rape but reveal higher concentrations of lead, iron and copper. Rye grass and maize, as the other grass species, do not acidify their rhizosphere or change the redox potential in the case of nutrient deficiency. They opt for another strategy, releasing organic ligands and particularly phytosiderophores to complex Fe III $[1,10]$. As a consequence, the plant species using this mechanism for nutrient mobilisation seem to absorb $\mathrm{Fe}$ with a better efficiency than rape for instance. However, phytosiderophores also form complexes with other metals such as zinc, copper and manganese, so increasing their rate of uptake by enhancing the metal mobility in the rhizosphere. The high concentrations of copper and lead could thus be explained in the same way, by the property of these elements to form stronger complexes with organic matter rather than zinc and cadmium.

\subsection{Leachate study}

Figures 2 and 3 present the average and the standard deviation of leachate measures of the pots of each plant and of the references pots. These graphical results are completed by a statistical study (Tab. III), which allows the comparison of the monitored parameters $(\mathrm{pH}, \mathrm{Eh}$, conductivity, DOC) and the heavy metal concentrations, between the different plant species and the reference pots.

Figure 2 and Table III reveal that the $\mathrm{pH}$ of the rape leachates is slightly lower than the three other types. This acidification is in good agreement with the literature data $[10,20]$ and as cited above, is concordant with the high concentrations of zinc and cadmium measured in rape roots and shoots. Despite some fluctuations, it could also be seen that the oxydo reduction potential is slightly lower for the reference pots than the cultivated ones. This indication is shown by the curves and the statistical studies argue that the growth of the plants could induce a better aeration of the sediments. As cited in the introduction this aeration can be generated by the mechanical action of the vegetal root system. For instance, the root development could modify the initial structure, compact and clayey, of the sediment to form a more aerated structure. This hypothesis is in good agreement with visual observations of the sediment structure after the pots have been dismantled. Especially, in the case of rape and rye grass, a very dense root hair system was developed, occupying the entire volume of the pots. Moreover, red traces in the vicinity of roots as observed in several pots, indicated that an iron oxidation occurred in the rhizosphere.

The leachate conductivity measured for the reference pots are very stable and, for some points, are two to three times lower than for maize and rye grass, indicating that the vegetation increases the mobility of ionic species. In the same way, COD concentrations leached from pots without plants are also lower than in the presence of vegetation. Thus, 

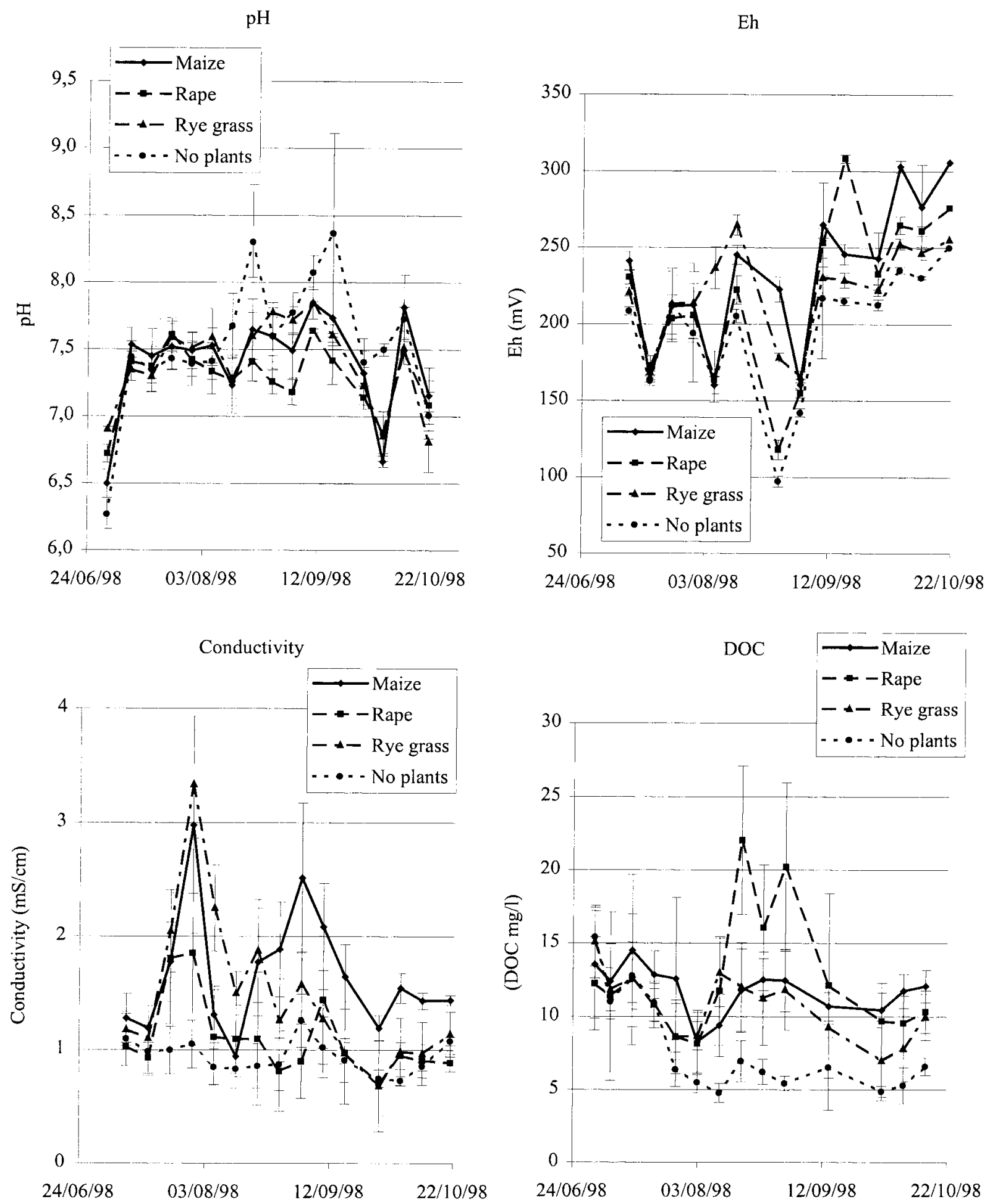

Figure 2. Evolution, over four months of $\mathrm{pH}$, Eh, conductivity and DOC concentrations in leachates sampled under sediments cultivated with maize, rape and rye grass and under bare sediments (test pots). 

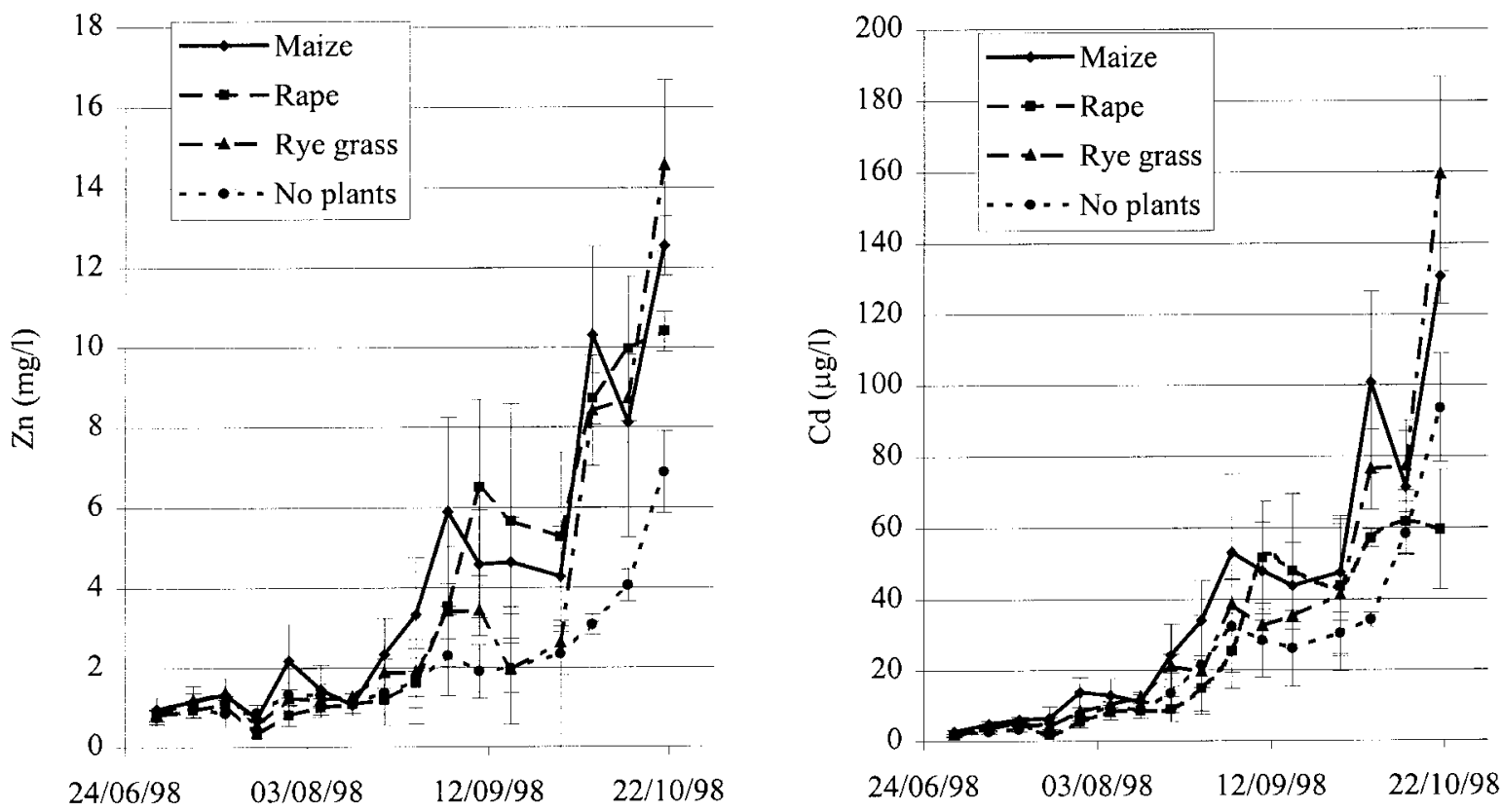

Copper concentration in leachates

Lead concentration in leachates
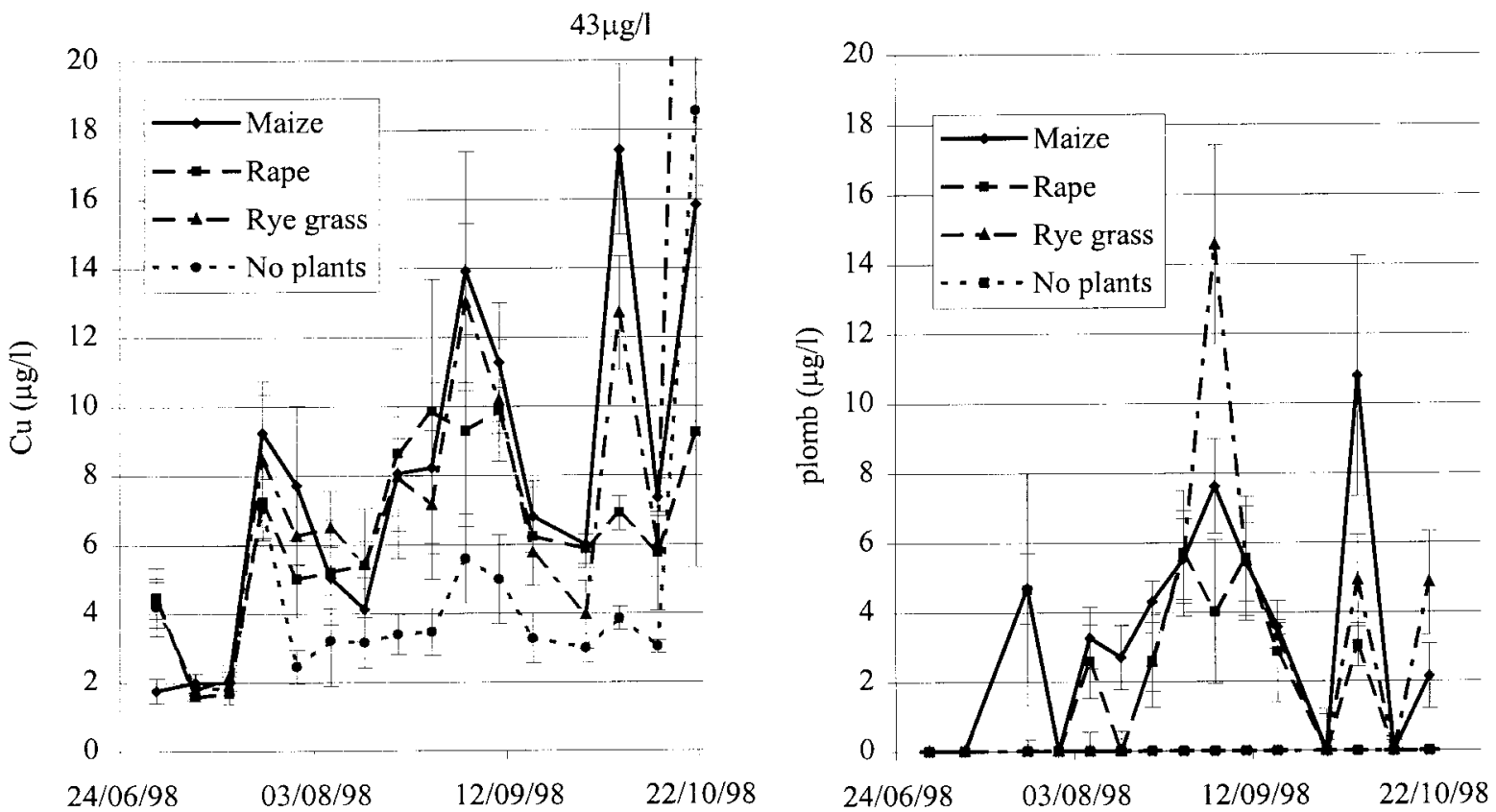

Figure 3. Evolution, over four months of $\mathrm{Zn}, \mathrm{Cd}, \mathrm{Cu}$ and $\mathrm{Pb}$ concentrations in leachates sampled under sediments cultivated with maize, rape and rye grass and under bare sediments (test pots). 
Table III. Results of the Kruskal-Wallis test on leachate characteristics and comparison of the median values for two significantly different populations. Abbreviations used: T: test pots without plants; M: maize; RA: rape; Ry: rye grass; $=$ when the populations studied are not significantly different.

\begin{tabular}{|c|c|c|c|c|c|c|c|c|c|c|c|c|}
\hline & $\mathrm{pH}$ & Eh & Cond. & DOC & $\mathrm{Zn}$ & $\mathrm{Cd}$ & $\mathrm{Cu}$ & $\mathrm{Pb}$ & $\mathrm{Mn}$ & $\mathrm{Fe}$ & $\mathrm{P}$ & Volume \\
\hline Test pots/maize & $=$ & $\mathrm{T}<\mathrm{M}$ & $\mathrm{T}<\mathrm{M}$ & $\mathrm{T}<\mathrm{M}$ & $\mathrm{T}<\mathrm{M}$ & $\mathrm{T}<\mathrm{M}$ & $\mathrm{T}<\mathrm{M}$ & $\mathrm{T}<\mathrm{M}$ & $\mathrm{T}<\mathrm{M}$ & $=$ & $\mathrm{T}<\mathrm{M}$ & $M<T$ \\
\hline Test pots/rape & $\mathrm{Ra}<\mathrm{T}$ & $\mathrm{T}<\mathrm{Ra}$ & $=$ & $\mathrm{T}<\mathrm{Ra}$ & $=$ & $=$ & $\mathrm{T}<\mathrm{Ra}$ & $\mathrm{T}<\mathrm{Ra}$ & $\mathrm{T}<\mathrm{Ra}$ & $=$ & $\mathrm{Ra}<\mathrm{T}$ & $\mathrm{Ra}<\mathrm{T}$ \\
\hline Test pots/rye grass & $=$ & $\mathrm{T}<\mathrm{R}$ & $\mathrm{T}<\mathrm{R}$ & $\mathrm{T}<\mathrm{R}$ & $\mathrm{T}<\mathrm{R}$ & $=$ & $\mathrm{T}<\mathrm{R}$ & $\mathrm{T}<\mathrm{R}$ & $\mathrm{T}<\mathrm{R}$ & $=$ & $\mathrm{T}<\mathrm{R}$ & $\mathrm{R}<\mathrm{T}$ \\
\hline Maize/rape & $\mathrm{Ra}<\mathrm{M}$ & $=$ & $\mathrm{Ra}<\mathrm{M}$ & $=$ & $=$ & $\mathrm{Ra}<\mathrm{M}$ & $=$ & $\mathrm{Ra}<\mathrm{M}$ & $\mathrm{Ra}<\mathrm{M}$ & $=$ & $\mathrm{Ra}<\mathrm{M}$ & $=$ \\
\hline Maize/rye grass & $=$ & $=$ & $=$ & Ry $<\mathrm{M}$ & $=$ & $=$ & $=$ & $\mathrm{Ry}<\mathrm{M}$ & $\mathrm{Ry}<\mathrm{M}$ & $=$ & $=$ & $=$ \\
\hline Rape /rye grass & $\mathrm{Ra}<\mathrm{Ry}$ & $=$ & $\mathrm{Ra}<\mathrm{Ry}$ & $=$ & $=$ & $=$ & $=$ & $=$ & $=$ & $=$ & $=$ & $=$ \\
\hline
\end{tabular}

the establishment of a vegetal cover induces a large increase of organic compounds in solution which could be produced either by the plants themselves (root exudates) or by the micro organisms activity. This activity can be enhanced by the release of some labile carbon by the plant and the better aeration of the matrix (better development conditions).

Figure 3 shows the evolution of heavy metal concentrations from June to October. Differences appear between the concentrations of heavy metals leached from contaminated sediments with and without vegetation. For zinc, lead, cadmium and copper the concentrations of heavy metal leached from the pots with plants are higher than for the reference pots. These results reveal the impact of plants on the physico-chemical characteristics of the sediment, which so seem to induce an evolution of the trace element contents in solution.

At this stage, different mechanisms can be inferred from these observations to explain the enhanced mobility of the metallic pollutants. Firstly, as cited above, it seems that the root system development induces a modification of the sediment structure, leading to an oxidation of the matrix. The consequences of such a dredged sediment oxidation on metal speciation and mobility were studied by many authors $[8,15,24]$. During this process, the sulphide minerals contained in the anaerobic sediments are oxidised, so liberating protons and sulphates in solution. As a consequence, the leaching waters generally exhibit a conductivity increase. Moreover, one of the most important consequences of the sediment oxidation lies in the fact that the heavy metal speciation is greatly affected by this process. In most cases, the heavy metal chemical forms, initially present as sulphide and hardly extractable forms, are progressively evolving to more exchangeable forms. As a consequence, the oxidation of reduced dredged sediments is cited to be one of the primary mechanisms leading to a higher mobility of heavy metals.

An observation can be made concerning the behaviour of copper and lead. These two elements show higher concentrations in leachates between the beginning of August and the end of September, which coincide with high concentrations of DOC. Copper and lead are well known to exhibit a great affinity for the organic matter [22]. In sediments [8] and in soil solution [13], a large part of lead and copper is associated with organic matter. Thus, two possible explanations can be given for the evolution of these elements: (1) $\mathrm{Cu}$ and $\mathrm{Pb}$ are complexed and maintained in solution by the labile organic carbon produced in solution by vegetal and microbial activity; (2) the higher aeration of the sediment matrix and the production of labile organic carbon by the vegetation (root exudates) may lead to an increase of microbial activity and to the increase of aerobic biodegradation of the organic matter present in sediment [20]. Enhanced degradation and solubilisation of organic matter in the presence of a vegetal cover may thus increase the release of metal ions which are associated to organic substrates. Degradation of the organic matter has been reported by Maass and Miehlich [19] as the process governing the solubilisation of copper and lead from dredged sediment deposits. However, in the absence of vegetation, this process is supposed to be very slow and to last over geological time-scales.

An evolution with time is equally obvious for all the plants studied and for reference pots. At the end of the monitoring, a slight decrease in the $\mathrm{pH}$ of the 
sediment solution is measured. This coincides with the increase in the mobilisation of zinc, cadmium, iron and copper. Since the acidification is also observed for reference pots, it cannot be due to the growth of the vegetation. It can thus be concluded that the oxidation-acidification is, instead due to the oxidation of the sediment by the incoming water. Such a behaviour has already been observed on an experimental deposit, set up in order to evaluate the impact of polluted dredged sediments on an agricultural soil [24].

However, the $\mathrm{pH}$ decrease measured in leachates is not confirmed by an evolution of the sediment matrix $\mathrm{pH}$ which stays at 7.4 from the beginning to the end of the monitoring period. This can be explained by the fact that the sediments used in this study contain an important quantity of calcite [11]. Hence, the evolution of the $\mathrm{pH}$ of the matrix is very weak because the calcite dissolution acts as a buffer against acidification. The dissolution of calcite is confirmed by the presence of high concentrations of calcium (around $200 \mathrm{mg} / \mathrm{L}$ ) in solution observed during the whole experimental period.

\section{Conclusion}

The primary results of this study indicate that the establishment of a vegetal cover (maize, rape and rye grass) on dredged sediments can quantitatively modify the physico-chemical parameters of the matrix, and so increase the mobility of heavy metals contained in the sediments. These modifications result in: (i) an increase of the redox potential due to the mechanical action of plant roots, thus enhancing the oxidation of the sediments and the release of the metallic pollutants; (ii) a decrease of the leachate $\mathrm{pH}$ in the case of rape, due to the production of acids by this plant; (iii) the production of soluble organic compounds exuded in the rhizosphere by the vegetals and micro-organisms. These compounds can act as ligands toward heavy metals, thus enhancing their mobility; (iv) the increase of the sediment micro-biological activity which can result in an intensified degradation of organic matter and thus in a release of the heavy metals associated to it.
However, the changes in $\mathrm{pH}$ induced by rape seem to have little effect on heavy metals mobility compared to the other species. Conversely, the increase of DOC and ionic species concentrations in solution show a larger impact on heavy metal mobility.

Nevertheless, in order to evaluate the total impact of these sediment deposits on their environment, these primary results have to be completed by a field study to take into account the physical parameters, as the decrease of hydric transfer throughout the profile due to evapotranspiration and the decrease of runoff due to hydric and eolian erosion.

Acknowledgements: We thank M. Salvignole and M. Tellier of the agricultural high school of Wagnonville (Douai) and M. Pavageot of the "Voies Navigables de France" for their technical help.

\section{References}

[1] Awad F., Römheld V., Marshner H., Effect of root exudates on mobilization in the rhizosphere and uptake of iron by wheat plants, Plant Soil 165 (1994) 213-218.

[2] Baker A.J.M., Brooks R.R., Terrestrial higher plants which hyperaccumulate metallic element - A review of their distribution, ecology and phytochemistry, Biorecovery 1 (1989) 81-126.

[3] Banks M.K., Schwab A.P., Fleming G.R., Hetrick B.A., Effect of plants and soil microflora on leaching of zinc from mine tailings, Chemosphere 29 (1994) 1691-1699.

[4] Banks M.K., Waters C.Y., Schwab A.P., Influence of organic acids on leaching of heavy metals from contaminated mine tailings, J. Environ. Sci. Health A29 (1994) 1045-1056.

[5] Bogusz D., Traitement des sédiments et des boues toxiques : état des études et des travaux menés en France, commun. sém., Environnement Nord Pas-de-Calais Quebec, Lille, Oct. 1997.

[6] Deroubaix P., Mise en place d'un protocole de minéralisation et application à des végétaux développés sur sédiments pollués, Rapp. CNRSSP 1998/23, 1998.

[7] Ernst W.H.O., Response of plants and vegetation to mine tailings and dredged materials, in: Salomons W., Förstner U. (Eds.), Chemistry and Biology of Solid Waste: Dredged Material and Mine Tailing, Springer Verlag, Berlin, 1988, pp. 54-69. 
[8] Gambrell R.P., Wiesepape J.B., Patrick W.H., Duff M.C., The effects of $\mathrm{pH}$, redox potential, and salinity on metal release from contaminated sediment, Water, Air, and Soil Pollut. 57-58 (1991) 359-367.

[9] Hamon R.E., McLaughlin M.J., Use of the hyperaccumulator Thlaspi caerulescens for bioavailable contaminant stripping, Proc. 5th Int. Conf., Biogeochemistry of Trace Elements, Vienna, 11-15 July, 1999.

[10] Hinsinger, The acquisition of mineral nutrients by roots: rhizosphere processes, Proc. 3rd Eur. Soc. Agron. Congr., Abova-Padova, 1994, pp. 427-437.

[11] Isaure M.P., Transfert et spéciation du zinc dans un dépôt de sédiment pollué et le sol sous-jacent : évolution spatio-temporelle le long du profil pédologique. Première année de suivi, Rapp. CNRSSP/1998/35, 1998.

[12] Isaure M.P., Laboudigue A., Lecomte P., Manceau A., Tiffreau C., Transfer of zinc from dredged toxic sediments to a soil: first characterization of the sediment, Proc. 5th. Int. Conf., Biogeochemistry of Trace Elements, Vienna, 11-15 July, 1999.

[13] Juste C., Matières organiques et comportement des éléments traces dans le sol, $5^{\mathrm{e}}$ forum de la fertilisation raisonnée, Blois, 1993, pp. 115-123.

[14] Kabata-Pendias A., Pendias H., Trace Elements in Soils and Plants. 2nd ed., CRC Press, Boca Raton, FL., 1992.

[15] Kersten M., Förstner U., Chemical fractionnation of heavy metals in anoxic estuarine and coastal sediments, Water Sci. Technol. 18 (1986) 121-130.

[16] Knight B., Zhao F.J., McGrath S.P., Shen Z.G., Zinc and cadmium uptake by the hyperaccumulator Thlaspi caerulescens in contaminated soils and its effects on the concentration and chemical speciation of metals in soil solution, Plant and Soil 197 (1997) 71-78.

[17] Lasat M.M., Baker A.J.M., Kochian L.V., Physiological characterisation of root $\mathrm{Zn}^{2+}$ absorption and translocation to shoots in Zn hyperaccumulator and non accumulator species of Thlaspi, Plant Physiol. 112 (1996) 1715-1722.

[18] Lombi E., Zhao F.J., McGrath S.P., Strategies for reducing pollutant flow from contaminated land, Proc.
Int. Conf., Investigation Methods on Soil Contamination, Lisbon, June 24-25, 1999.

[19] Maass B., Miehlich G., Die Wirkung des Redoxpotentials auf die Zusammensetzung der Porenlösung in Hafenschlickspülfeldern, Mitt. Dtsch. Bodenkd. Ges. 56 (1988) 289-294.

[20] Marshner H., Mineral Nutrition of Higher Plants, 2nd ed., Academic Press, Harcourt Brace \& Co., 1995.

[21] McGrath S.P., Shen Z.G., and Zhao F.J., Heavy metal uptake and chemical changes in the rhizosphere of Thlaspi caerulescens and Thlasiy ochroleucum grown in contaminated soils, Plant and Soil 188 (1997) 153-159.

[22] Ross S.M. (Ed.), Toxic Metal in Soil-Plant Systems, John Wiley \& Sons, UK, 1994.

[23] Shetty K.G., Hetrick B.A.D., Figge D.A.H., Schwab A.P., Effect of mycorrhizae and other soil microbes on revegetation of heavy metal contaminated mine spoil, Environ. Pollut. 86 (1994) 181-188.

[24] Tack F.M., Callewaert O.W.J.J., Verloo M.G., Metal solubility as a function of $\mathrm{pH}$ in a contaminated, dredged sediment affected by oxidation, Environ. Pollut. 91 (1996) 199-208.

[25] Tack F.M., Singh S.P., Verloo M.G., Leaching behaviour of $\mathrm{Cd}, \mathrm{Cu}, \mathrm{Pb}$ and zinc in surface soils derived from dredged sediments, Environ. Pollut. 106 (1999) 107-114.

[26] Tiffreau C., Problématique des sédiments toxiques : impact sur un sol non pollué du dépôt de sédiments contaminés, Rapp. CNRSSP, 1998/22, 1998.

[27] Tiffreau C., Marseille F., Isaure M.P., Lors C., Laboudigue A., Branchu P., Lecomte P., Impact of contaminated dredged sediment deposits on clean soils: an interdisciplinary study of the mobility and bioavailability of the metallic pollution, Proc. 4th Congr., Characterization and Treatment of Sediments, September 15-17, 1999.

[28] Vangronsveld J., Sterckx J., Van Assche F., Clijsters, Rehabilitation studies on an old non-ferrous waste dumping ground: effects of revegetation and metal immobilisation by beringite, J. Geochem. Explor. 52 (1995) 221-229. 